\title{
ATTRACTIVENESS OF THE EASTERN AUKŠTAITIJA REGION FOR LOCAL TOURISM UNDER COVID-19 CONDITIONS
}

\author{
Ramutė Narkūnienė \\ Mykolas Romeris University, Utena University of Applied Sciences, Lithuania
}

\begin{abstract}
The article discusses the attractiveness factors of the Eastern Aukštaitija region for local tourism under COVID - 19 conditions and presents the results of the research (analysis of scientific literature, questionnaire surveys and analysis of strategic documents). The aim of the research is to perform an analysis of the attractiveness of the Eastern Aukštaitija region for local tourism under COVID-19 conditions. Objectives of the research: to describe the factors of tourism region's attractiveness for local tourism; to perform an analysis of the attractiveness of the Eastern Aukštaitija region for local tourism under COVID-19 conditions. An analysis of the scientific literature showed that destination attractions define the framework within which visitors enjoy their vacations. They include all forms of natural and created (manmade) resources, culture, heritage, history, customs, architectural features, traditional artwork, cuisine, music and handicrafts that attract travellers. According to the results of the research, the choice of travels in the Eastern Aukštaitija region is mostly influenced by such factors of attractiveness of the region as natural resources, cultural resources and interesting places of interest, as well as attractiveness of the tourism destination/ region.
\end{abstract}

Keywords: attractiveness of the region, Eastern Aukštaitija region, local tourism.

\section{Introduction}

Relevance of the Topic. At the end of the 2019 year, the travel and tourism industry ranked almost $9 \%$ on the world economic map. However, the pandemic COVID-19 stopped the sector instantly. The global crisis caused by the COVID-19 pandemic has had a huge impact on tourism development. The UN WTO predicts that the number of tourists worldwide in 2020 may decrease by 20-30\% - from 1.46 billion incoming tourists in 2019 to $1.02-1.17$ billion this year. This fall could make 300 - 450 billion USD financial loss (United Nations World Tourism Organization, 2020). However, the pandemic did not stop local tourism: the COVID-19 pandemic saw a tremendous increase in the importance of local tourism. The pandemic adjusted the holiday plans of many Lithuanians, but this did not reduce the desire to travel around their country. In 2019 local tourists accounted for more than half of the total tourism market in Lithuania, and 
in 2020, due to the pandemic, local tourism increased by $12 \%$ compared to 2019 (data of the National Lithuanian Tourism Promotion Agency "Travel in Lithuania", 2021). Even during a pandemic, each tourism destination / region seeks to attract more tourists and maintain economic growth and stable jobs. Eastern Aukštaitija region is one of the six priority tourism regions in Lithuania, an important region in Lithuania in terms of tourism development.

The attractiveness of the tourist region has been analyzed by a number of foreign researches, as (Mayo \& Jarvis, 1981; Haathi, 1986; Lew, 1987; Middleton, 1989; Gartner, 1989; Leiper, 1990; Hu \& Ritchie, 1993; Crouch \& Ritchie, 1999; Prideaux, 2000b; Berardi, 2002; Kim \& Lee, 2002; Falk, 2002; Klenosky, 2002; Dwyer, Livaic, \& Mellor, 2003; Enright et al., 2004; Formica, 2002; Garau-Taberner, 2007; Vengesayi, Mavondo, \& Reisinger, 2009 and others). In Lithuania, this topic was analyzed by Malinauskaite, 2017; Labanauskaite, 2020, 2015; Jonuškienè, 2015, Andrulienè et al., 2011 and others. However, the factors of attractiveness of the tourist region in Lithuania have not been analyzed in detail, only individual researches are being conducted.

The object of the research is the attractiveness of the Eastern Aukštaitija region for local tourism under COVID-19 conditions.

The aim of the research is to perform an analysis of the attractiveness of the Eastern Aukštaitija region for local tourism under COVID-19 conditions.

Objectives of the research:

1. To describe the factors of tourism region's attractiveness for local tourism;

2. To perform an analysis of the attractiveness of the Eastern Aukštaitija region for local tourism under COVID-19 conditions.

Methodology of Research. The analysis of scientific literature sources, quantitative research - questionnaire survey method and data summarization were used in the article. In order to clarify the conditions and priorities of tourism development in the mentioned region, the analysis of documents was performed. According the specifics of the study, this method should be considered an important method of data collection. Sources of data to be collected: Law on Tourism of the Republic of Lithuania, Lithuanian Tourism Development Programme for 2014-2020, Utena Region Development 2014-2020 plan, Study of Lithuanian Tourism Potential Assessment in Determining the Maximum Tourist Attraction Areas and Priorities for Their Uses (2011), and other documents.

The survey sample. The sample size for the research was calculated according to the Schwarze formula. 102 respondents took part in the survey (according to the formula, 96 respondents are sufficient to ensure the representativeness of the survey sample). The questionnaire was processed with the Excel programme. Respondents from Vilnius (41 \%), Eastern Aukštaitija 
(24\%), Pajūris (15\%), Lower Nemunas (6\%), South Dzūkija (3\%) and Žemaitijos highlands (3\%) regions participated in the survey; $9 \%$ of respondents were Lithuanian emigrants currently living in foreign countries: Germany, Great Britain, Norway, and etc.

\section{The Scientific Discussion of the Attractiveness of a Tourism Region}

The attractiveness of a tourism destination is often related to the opinion of visitors about the perceived ability of the tourism destination to meet its needs. Mayo and Jarvis (1981) define the attractiveness of touristic areas as "the relative importance of individual benefits and the perceived ability of the destination to provide these individual benefits" (p. 201), i.e., places of interest, infrastructure or services, and the people who provide these services. Places of interest are more significant for the assessment of tourist attractiveness personal characteristics: age, education, financial situation, belonging to a certain social stratum, profession and current position (Berardi, 2002). According to $\mathrm{Hu}$ and Ritchie (1993), a tourism destination is a combination of tourism facilities and services. Gartner (1989) points to several other features of a tourism destination's attractiveness, including historical and cultural sites, nightlife, outdoor living, the natural environment, and more.

Surveys of tourists visiting Italy have found that the assessment of the tourism attractiveness of a country and its individual regions is significantly influenced by (Garau-Taberner, 2007): 1) distance to the tourist destination; 2) time; 3) travel price; 4) purpose of travel; 5) the reputation of the area between travellers and tour operators; 6) security; 7) culture (Labanauskaite, 2020).

The tourism attractiveness of the tourism destination visited is often linked to the feelings of the visitors and the opinion of how much and how the tourism destination is able to meet their needs. The more a tourism destination meets the needs of tourists, the more often it is perceived as attractive and the more likely it is to be chosen by potential customers. Analysis of the assessment of the tourism attractiveness of the tourism destination visited and the identification of attractiveness factors contribute to strengthening the ability to create personalized value for the visitor, which in turn becomes an integral part of a competitive strategy (Enright et al., 2005). Research on the attractiveness of the tourism destination visited focuses on the needs of tourists and what attracts them to the various attractions.

Different destinations have different images and thus attract different people (Gartner, 1989; Haahti, 1986). Tourist attractions include all kinds of natural and man-made resources, culture, heritage, history, customs, architectural features, traditional works of art, cuisine, music and handicrafts that attract travellers (Crouch \& Ritchie, 1999; Goeldner \& Ritchie, 2006). Entertainment is the main 
criterion and motivator for choosing a place to visit, giving priority to one place to visit over others. Goeldner and Ritchie (2006) divide entertainment into five main groups: culture, nature, events, recreation and leisure. The variety of activities offered in the tourism destination visited is an important attraction when choosing a trip. The attractiveness of the tourism destination visited also depends on the ability to create infrastructure for tourists.

According to the "Study of Lithuanian Tourism Potential Assessment in Determining the Maximum Tourist Attraction Areas and Priorities for Their Use's" (2011), the structure of tourist attractiveness of a tourism destination / region consists of: tourism resources (natural, cultural, social / human) and infrastructure; components of the tourism industry (accommodation, catering, transport, entertainment, information, management, travel, training services); tourist flow; the status of the site (resort, UNESCO World Heritage Site, etc.); image of the tourism destination; activities of tourism stakeholders; location of the tourism destination in the tourism network. Figure 1 shows the structure of the tourism destination attractiveness factors.

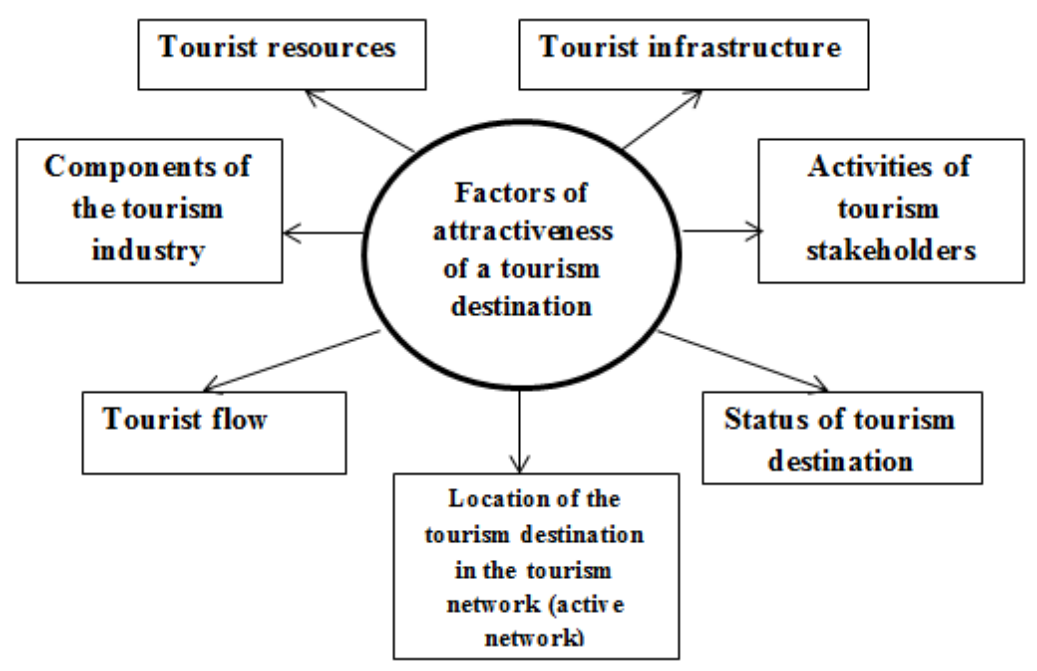

Figure 1 Structure of Tourism Destination Attractiveness Factors

(composed by the author according Andruliene et al., 2011)

Eastern Aukštaitija region is one of the priority tourism development regions identified in Lithuanian Tourism Development Programme for 2014-2020. The region has the largest number of rural tourism homesteads in Lithuania according to statistical data of 2017, 168 rural tourism homesteads or $25 \%$ of all Lithuanian rural tourism homesteads operated here, 3 resort areas (Anykščiai, Zarasai and Ignalina) and 1002 lakes. The region of Eastern Aukštaitija is distinguished by the abundance of state protected areas - protected areas cover an area of 147345.73 ha (20.46\% of the region's territory). The largest areas in the 
region are occupied by state parks, the following types of tourism are being developed: cognitive cultural tourism; leisure; rural; health tourism, ecotourism.

According to the "Study of Lithuanian Tourism Potential Assessment in Determining the Maximum Tourist Attraction Areas and Priorities for Their Uses (2011), the results of comprehensive assessment of attractiveness of Eastern Aukštaitija region districts are distributed as follows: Anykščiai district is evaluated by 8.68 points, Ignalina district - by 21.03 points, Molètai district 12.37 points, Utena district - 9.82 points and Zarasai district - 21.98 points (for comparison, the highest score in assessing Lithuanian districts is 50.26 and the lowest score - 3.81).

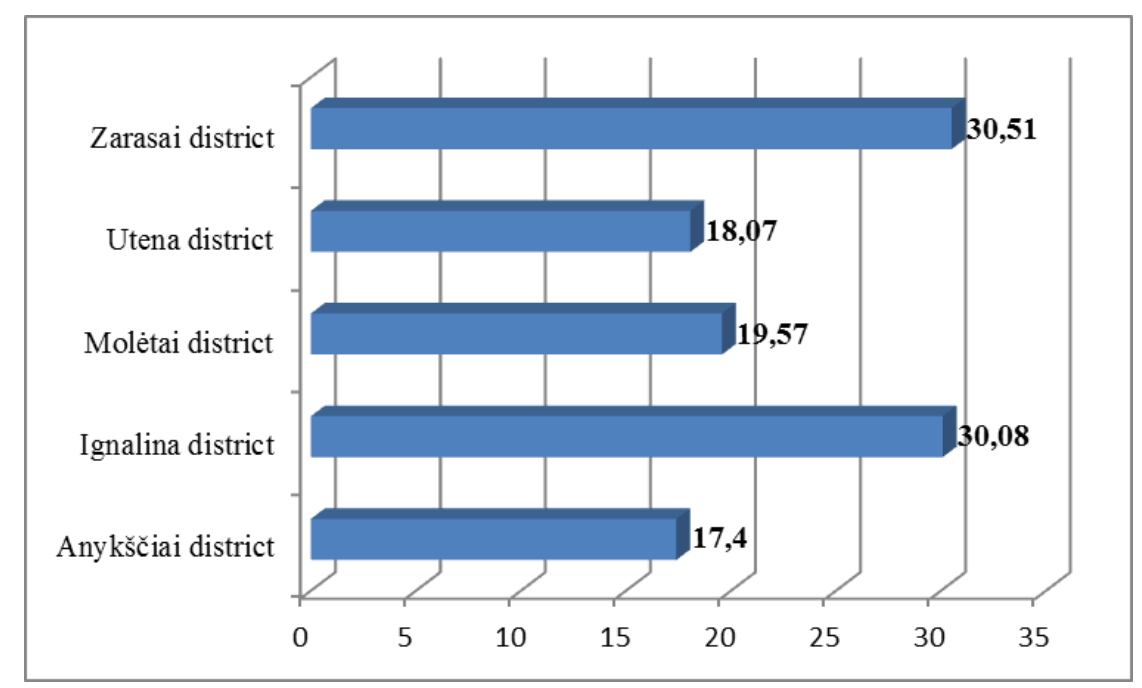

Figure 2 Overall Results of the Cumulative Assessment of the Attractiveness of the Districts of the Eastern Aukštaitija Region, Points (composed by the author according "Study of Lithuanian Tourism Potential Assessment in Determining the Maximum Tourist Attraction Areas and Priorities for Their Uses, 2011)

Overall summary results of the evaluation of tourism services and infrastructure (catering, accommodation, communication, tourism information, travel organization services, tourist flows, staff, tourism infrastructure objects); tourism resources, picturesque landscape, environmental quality, cultural objects); status criteria (resort area, resort, protected areas, UNESCO World Cultural Heritage) are distributed in the following order: Anykščiai district is evaluated with 17.40 points, Ignalina district - with 30.08 points, Moletai district with 19.57 points, Utena district - with 18.07 and Zarasai district - 30.51 points (for comparison, the highest score in the evaluation of Lithuanian districts is 80.44 and the lowest score - 6.32). The overall results of the cumulative assessment are presented in Figure 2. 
Narkūnienè, 2021. Attractiveness of the Eastern Aukštaitija Region for Local Tourism Under Covid-19 Conditions

\section{Analysis of the Research of the Attractiveness of the Eastern Aukštaitija Region for Local Tourism in the Conditions of COVID-19}

Methodology of Research. The method of quantitative research chosen for the research is a questionnaire survey, surveying tourists traveling around Lithuania. The methodology of quantitative research is based on a positivist (normative) paradigm that explains social reality from an objectivist point of view. The survey was conducted from December 2020 to January 2021, by placing the questionnaire on the survey portal www.apklausa.lt and distributing the questionnaire among the representatives of other Lithuanian regions. The sample size for the study was calculated according to the Schwarz formula. The questionnaire consisted of 25 questions. 102 respondents from Vilnius (41\%), Eastern Aukštaitija (24 \%), Pajūris (15\%), Lower Nemunas (6 \%), South Dzūkija (3\%) and Žemaitija highland (3\%) regions participated in the survey. (According to the formula, 96 respondents are sufficient to ensure the representativeness of the survey sample); $9 \%$ respondents - emigrants from Lithuania, currently living in foreign countries: Germany, Great Britain and Norway, and etc.

Research results. According to the survey data, all surveyed respondents like to travel. Respondents most often travel for cognitive (28\%), recreational (23\%), entertaining (19\%) and other purposes. Decision-making when planning trips is mostly determined by the recommendations of friends, colleagues and acquaintances (31\%), the Internet (29\%), social networks (17\%), and $8 \%$ each - information and other sources of information found in the media and tourism information centres (TICs). Before the COVID-19 pandemic, a slightly higher share of respondents travelled to Lithuania (47\%), $44 \%$ of the respondents travelled to foreign countries, every tenth respondent travelled to both Lithuania and foreign countries.

The majority of the respondents (84\%) organize trips to Lithuania independently, $12 \%$ applies to travel companies, and $6 \%$ respondents behave differently. $35 \%$ respondents choose short, 1- 3 day trips, $29 \%$ choose trips of 7 days and longer, $27 \%$ - medium-term - 4 - 6 days of travel, $9 \%$ - journeys of various durations, depending on the purpose of the journey. A significant number of tourists travel on holiday time (38\%), one in three travels as soon as they find free time, and one in five travels on weekends. $15 \%$ respondents plan trips spontaneously, $9 \%$ - a month before, and seven out of ten respondents behave differently depending on the purpose and circumstances of the trip. $41 \%$ the travel time of the respondents is irrelevant, but four out of ten respondents travel during the summer and two out of ten travel during the autumn.

The vast majority of respondents (71 \%) travel with family members, 3 percent traveling alone, $12 \%$ respondents travel with friends and the same number of respondents travel differently depending on the situation. Slightly more than 
half of the respondents (53 \%) travel by car, $35 \%$ prefers an airplane, 3\% respondents travel by bus and $9 \%$ choose a variety of vehicles when traveling. Exactly half of the respondents (50\%) choose a hotel for overnight trips, $15 \%$ guest house, $9 \%$ - rural tourism homestead, $6 \%$ - camping, and $21 \%$ the respondents stay overnight with friends and relatives, rent an apartment or flats, etc.

$65 \%$ of respondents classified themselves as comfortable to travel and spend the night, $24 \%$ - who like to spend time in nature, respectively $6 \%$ of travellers tend to save, often choose free entertainment and like to buy travel packages, more often than others traveling with friends or a group of tours (In 2018, a survey was conducted by order of the State Tourism Department, in which 6 types of local tourists were distinguished for the first time. Using statistical methods, according to the different motivations and habits of tourism in Lithuania to travel in their country, the researchers ranked the following types of tourists: entertainers, "all inclusive", "peace with family", "nature lovers", "where everyone is" and "quality seekers"). When choosing trips around Lithuania, respondents find natural resources the most attractive (32\%), respectively $18 \%$ - cultural resources and good ratio for money and quality find the most attractive, $14 \%$ choose trips due to the attractiveness of the tourism destination / region, $10 \%$ of respondents - for events and $8 \%$ - due to high quality of service.

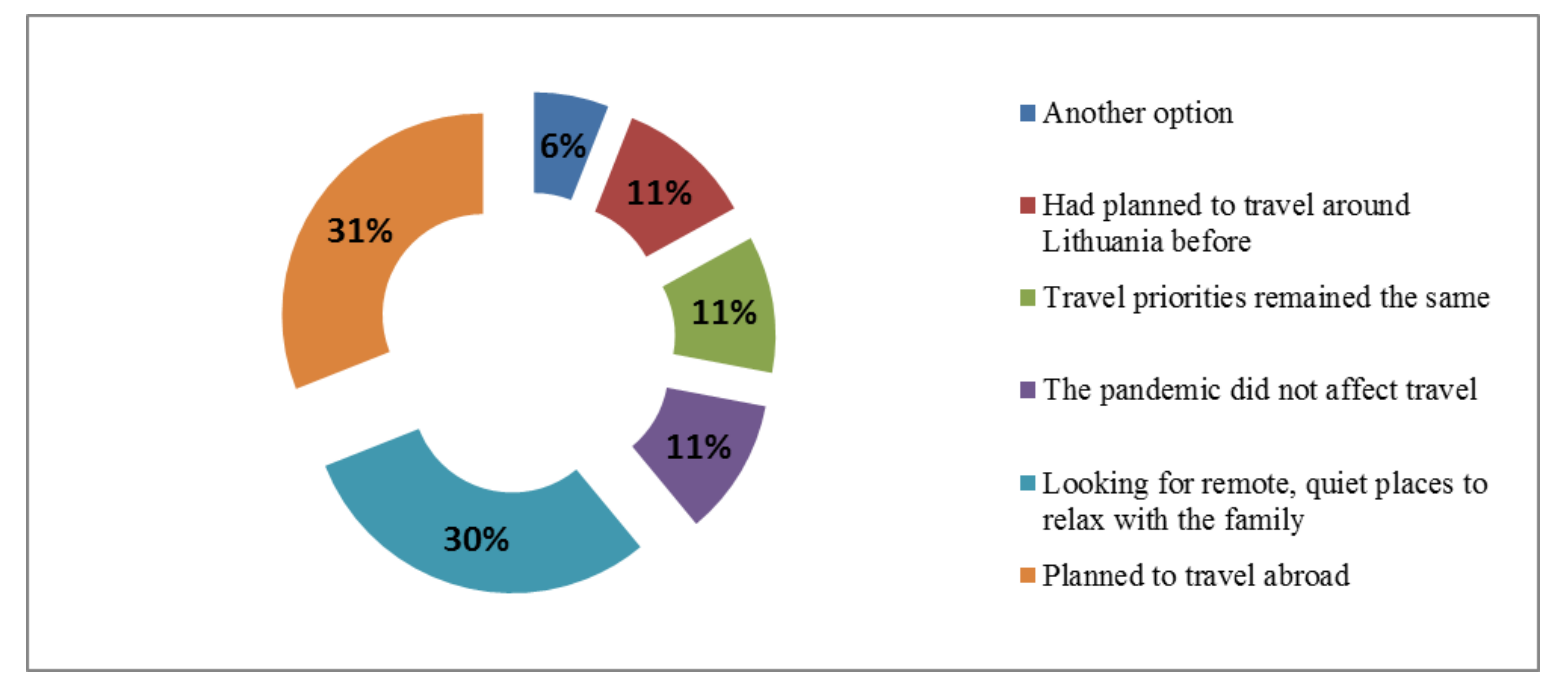

Figure 3 Impact of the COVID-19 Pandemic on Respondents' Travel Plans (composed by the author according research results)

The COVID-19 pandemic adjusted travellers plans: $31 \%$ respondents planned to travel abroad, but had to travel around Lithuania, three out of ten respondents, planning a trip, are looking for remote, quiet places to relax with their family during a pandemic, $22 \%$ respondents were not affected by the 
Narkūnienè, 2021. Attractiveness of the Eastern Aukštaitija Region for Local Tourism Under Covid-19 Conditions

pandemic; their travel priorities remained the same, $11 \%$ of respondents had previously planned to travel to Lithuania, $6 \%$ planned trips to foreign countries, but due to the pandemic it was necessary to choose the countries neighbouring Lithuania - Estonia, Latvia (see Figure 3).

The majority of respondents (91\%) have visited the Eastern Aukštaitija region earlier. Respondents' choice of trips when choosing trips in this region is most influenced by natural resources (lake region, Aukštaitija National Park, regional parks, forests, protected areas, beautiful landscape, etc.) - $21 \%$; interesting places of interest (Tree Crown Trail in Anykščiai, observation circle in Zarasai, narrow - gauge railway museum in Anykščiai, observation towers in various places in the region, etc.) - $14 \%$; cultural resources (churches, museums (Brewery Museum; Horse Museum; Vytautas Valiušis Ceramics Museum)), mills (Šlyninka mill in Zarasai, etc.), manors (Vasaknai manor, etc.) - 11 \%; image of the tourism destination / region, attractiveness - 10\%; a quiet place to relax with the family $-7 \%$; participation in educational programs (bread baking education (Anykščiai, Zarasai districts); painting on glass, education "Aukštaičiai dishes for the table of kings" (Molètai district); branch baking education (Ignalina district) $-7 \%$; recommendations from friends and acquaintances, good pricequality ratio $-7 \%$; participation in health programs (SPA, massages, etc.), sports events (rallies, moto crosses, etc.) and other events (event "Black Moon", events on the island of lake Zarasas, various celebrations, exhibitions, festivals, etc.) respectively $5 \%$, human resources (high quality of service) - $1 \%$ (See Figure 4).

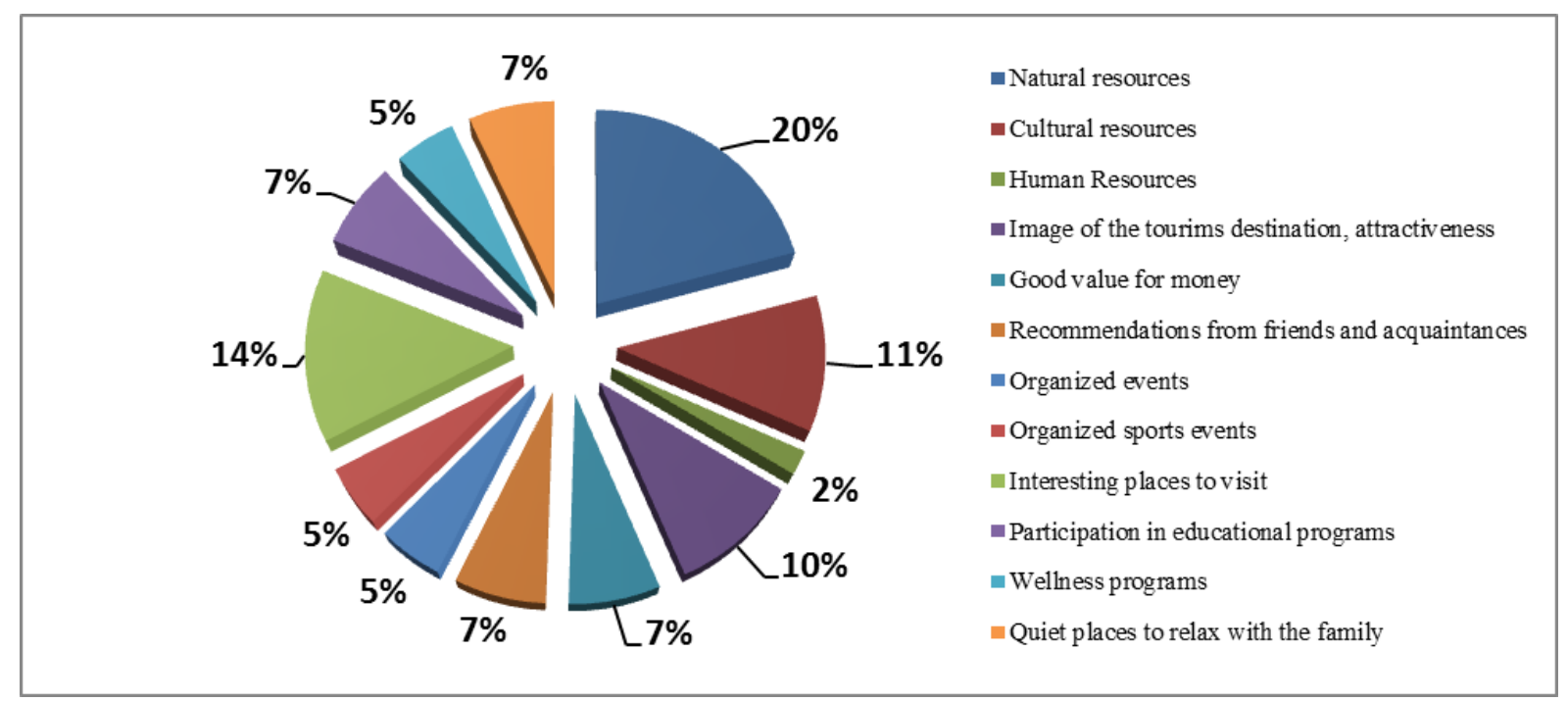

Figure 4 Factors Influencing Travel Choice in the Eastern Aukštaitija Region (composed by the author according research results)

Such research results only confirm the analysis of scientific literature sources and documents: all forms of natural and created (manmade) resources, culture, 
heritage, history, traditional artwork, cuisine, music and handicrafts attract travellers and make the tourism destination more attractive. $97 \%$ respondents would recommend Eastern Aukštaitija region as a travel destination for their friends and acquaintances. 83\% respondents would plan their trips to the Eastern Aukštaitija region and not during a pandemic.

$86 \%$ women and $14 \%$ men participated in the survey. By age groups, the distribution of respondents was as follows: $31 \%$ belonged to the 26-35 age group, $26 \%-56-65 ; 23 \%-36-45 ; 14 \%$ - 46-55 and $6 \%$ - for $18-25$ age groups. $46 \%$ of the respondents were employees of enterprises, 31\% - civil servants, $6 \%$ students, $3 \%$ - housewives, $3 \%$ work in an unskilled job, the rest have their own business, are freelance.

\section{Conclusions}

1. An analysis of the scientific literature showed that destination attractions define the framework within which visitors enjoy their vacations. They include all forms of natural and created (manmade) resources, culture, heritage, history, customs, architectural features, traditional artwork, cuisine, music and handicrafts that attract travellers.

2. When choosing trips around Lithuania, respondents find natural and cultural resources the most attractive, in second place - good ratio for money and quality, respectively choose trips due to the attractiveness of the tourism destination / region and etc. The choice of trips in the Eastern Aukštaitija region in the conditions of the COVID-19 pandemic is mostly influenced by natural resources $-21 \%$; interesting places to visit - $14 \%$; cultural resources - $11 \%$; image of the tourism destination / region, attractiveness - $10 \%$; quiet places to relax with family, participation in educational programs, recommendations from friends and acquaintances, good value for money - 7 $\%$ each - participation in health programs, sports events and other events - 5 $\%$ each, human resources) $-1 \%$.

\section{References}

Andrulienė, R., Armaitienè, A., Povilanskas, R., Janulienè, R., \& Dulskis, D. (2011). Study of Lithuanian Tourism Potential Assessment in Determining the Maximum Tourist Attraction Areas and Priorities for Their Uses. Vilnius.

Berardi, S. (2002). Development of tourism. Milano.

Crouch, G., \& Ritchie, B. (1999). Tourism, competitiveness, and societal prosperity. Journal of Business Research, 44, 137-152.

Dwyer, L., Livaic, Z., \& Mellor, R. (2003). Competitiveness of Australia as a tourist destination. Journal of Hospitality and Tourism Management, 10(1), 60-78. 
Narkūniene, 2021. Attractiveness of the Eastern Aukštaitija Region for Local Tourism Under Covid-19 Conditions

Enright, M., J., and Newton, J. (2005). Determinants of Tourism Destination Competitiveness in Asia Pacific: Comprehensiveness and Universality. Journal of Travel Research, Vol. 4, 1-12.

Falk, R. (2002). Communication: Means and ends in the struggle against global terrorism. Pacific Review, 14(1), 49-65.

Formica, S. (2002). Measuring destination attractiveness: A proposed framework. Journal of American Academy of Business, 1(2), 350-355.

Garau-Taberner J. (2007). Measuring destination competitiveness: an exploratory study of the Canaries, Mainland Spain, France, the Balearics and Italy. Tourism today, No. 7, 61-78.

Gartner, W. (1989). Tourism image: Attribute measurement of state tourism products using multidimensional scaling techniques. Journal of Travel Research, 28(2), 16-20.

Goeldner, Ch. R., \& Ritchie J. R. B. (2006). Tourism. Principles, Practices, Philosophies. John Willey \& Sons, INC, 577.

Haahti, A. (1986). Finland's competitive position as a destination. Annals of Tourism Research, 13, 11-35.

Hu, Y., \& Ritchie, B. (1993). Measuring destination attractiveness: A contextual approach. Journal of Travel Research, 25-34.

Labanauskaite, D., (2020). International Tourism Development and Economic Evaluation. Monograph. Klaipeda: Klaipeda University Publishing House.

Labanauskaitè, D., \& Jonuškienè, E. (2015). Assessment of changes in Lithuanian tourism attractiveness. Professional studies: theory and practice, 15, 98-103.

Labanauskaite, D., \& Gedvilas, E. (2014). Lithuanian tourism competitiveness in the context of Baltic countries. Regional Formation and Development Studies, No. 2(10)

Klenosky, D. (2002). The "pull” of tourism destinations: A means-end investigation. Journal of Travel Research, 40, 385-395.

Law on Tourism of the Republic of Lithuania. (2021). No. XIII-310, version in force from 01.01.2021.

Lithuanian Tourism Development programme for 2014-2020. (2013). Retrieved from https://mita.lrv.lt/uploads/mita/documents/files/_en/national-programmes/innovation-inlithuania/lithuanian_innovation_programme.pdf

Lew, A. (1987). A framework of tourist attraction research. Annals of Tourism Research, 14(4), 553-575.

Leiper, N. (1990). Tourist attraction systems. Annals of Tourism Research, 17, 367-384

Malinauskaite, V. (2017). Management of international tourism development is based on assessments of the region's attractiveness. Doctoral dissertation. Vilnius: VGTU.

Mayo, E., \& Jarvis, L. (1981). Psychology of leisure travel. Boston: CABI Publishing.

Middleton, V. (1989). Tourist product. In; F. S. Witt \& L. Moutinho (Eds.), Tourism marketing and management handbook. London: Prentice Hall.

Prideaux, B. (2000b). The resort development spectrum - a new approach to modelling resort development. Tourism Management, 21, 225-240.

Utena region development in 2014-2020 plan. (2014). Retrieved from: https://lietuvosregionai. lt/lt/8/utenos-regiono-pletros-2014-2020-metams-planas-273.html

United Nations World Tourism Organization. (2020). Retrieved from: https://www.unwto.org/ Vengesayj, S., \& Mavondo, F. (2009). Tourism destination attractiveness: Attractions, Facilities and People as Prediction. Tourism Analysis. DOI: 10.3727/108354 209X12597959359211, Retrieved from: https://www.researchgate.net/publication/ 233643032 